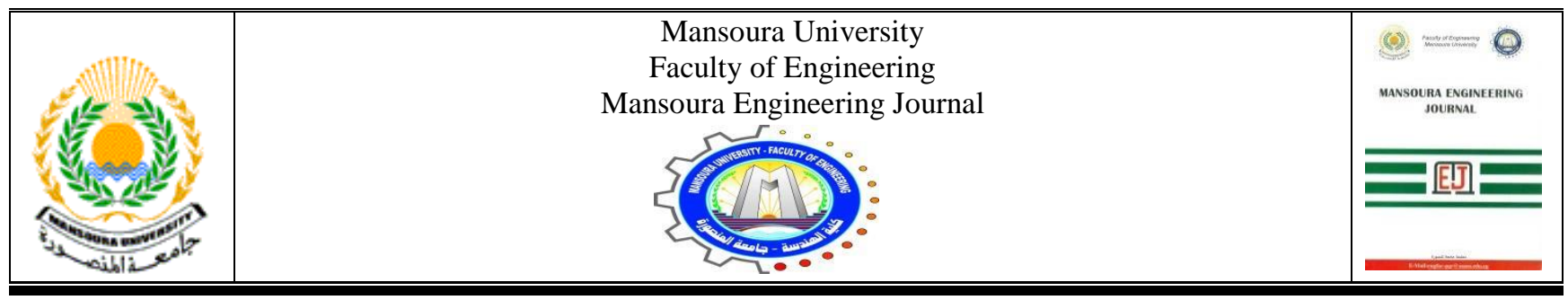

\title{
Experimental investigation on the performance of spherical solar collector for water heating
}

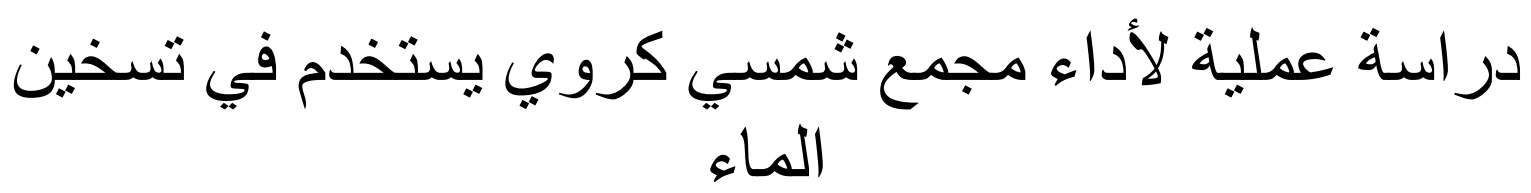

Mahmoud A. Elhefnawy, A. Ramzy Kattaya and M. M. Awad.

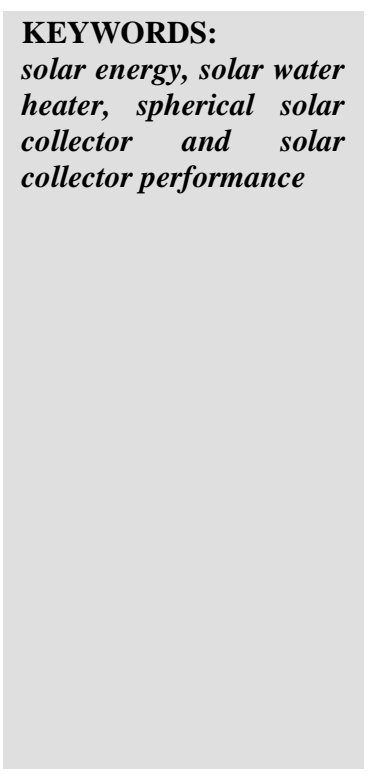

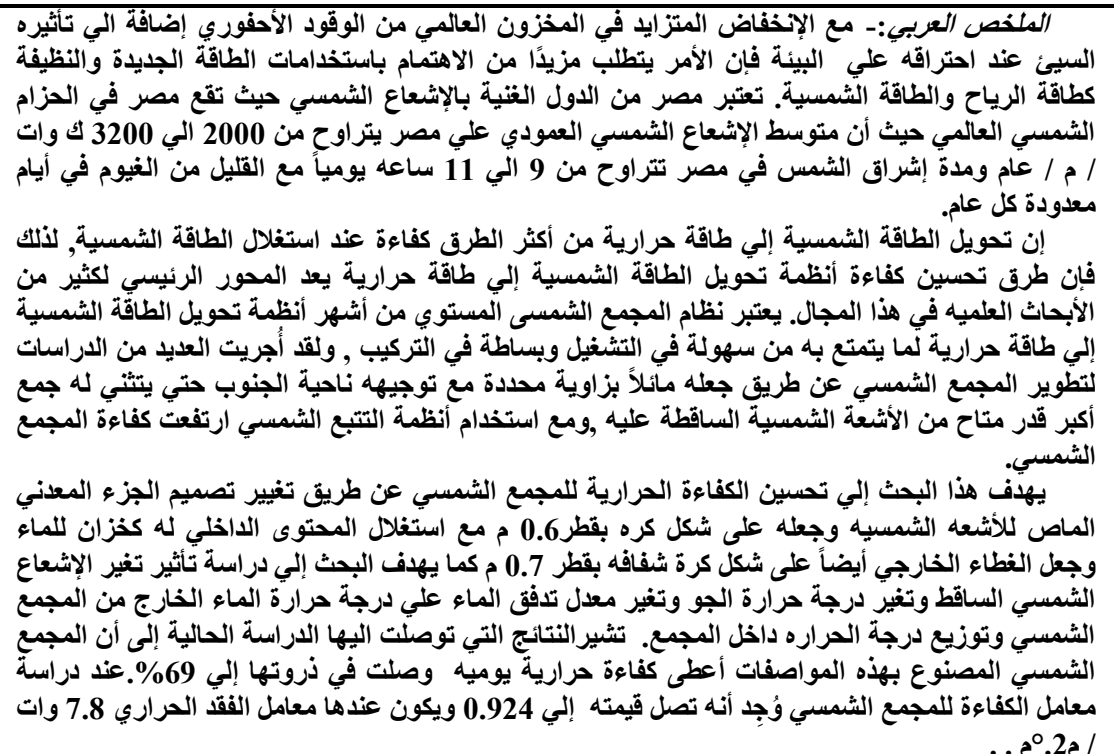

Abstract - Align with shortage of fossil fuel reserves, as well as the bad effects of using it on climate, more attention must be paid to renewable energy sources which including solar energy. Egypt is one of the Sunbelt countries. The solar Atlas, which was issued in 1991, shows that the average direct normal solar 2016.

Received: 28 April, 2016 - revised: 30 May, 2016 - accepted: 6 June,

Mahmoud A. Elhefnawy, a Damietta power plant, East Delta Electricity Production Co. - Egyptm (e-mail: mahelhefnawy@yahoo.com).

A. Ramzy Kattayab, Mech. power Eng. Dept., Faculty of engineering, Mansoura University (email: ahmed_ara1979@mans.edu.eg)

M. M. Awadb, Mech. power Eng. Dept., Faculty of engineering, Mansoura University (email: profawad@mans.edu.eg) radiation energy in Egypt is $2000-3200 \mathrm{kWh} / \mathrm{m} 2 /$ year. The sun shine duration ranges between 9-11 h/day with a few cloudy days [1].

One of the effective methods which are used to improve the performance of solar thermal energy conversion applications such as solar collectors is the design of the collector geometry. In the present work, the performance of a solar collector for water heating with spherical geometry design is investigated experimentally. The effects of incident solar radiation variation, ambient temperature changes and variation of water mass flow rate on the water outlet temperature and the performance of the collector were studied. The experiments were done at four different mass flow rates and non-flow rate.

The results show that the average daily efficiency of the spherical solar collector with $1.1304 \mathrm{~m} 2$ surface area of absorber and $0.6 \mathrm{~m}$ diameter reaches its peak of $69 \%$. The results also 
show that the collector efficiency factor was about 0.924 and the overall heat loss coefficient was $7.8 \mathrm{~W} / \mathrm{m} 2{ }^{\circ} \mathrm{C}$.

\begin{tabular}{|c|c|c|}
\hline & Nomenclature & \\
\hline $\mathrm{A}_{\mathrm{T}}$ & $\begin{array}{l}\text { total surface area of the } \\
\text { spherical solar collector }\end{array}$ & $\mathrm{m}^{2}$ \\
\hline$c_{p, w}$ & specific heat of water & $\mathrm{J} / \mathrm{kg}^{\circ} \mathrm{C}$ \\
\hline$\overline{\mathrm{F}}$ & collector efficiency factor & \\
\hline $\mathrm{G}_{\mathrm{Tsph}}$ & $\begin{array}{l}\text { total solar radiation incident } \\
\text { on the spherical solar collector } \\
\text { per unit surface area }\end{array}$ & $\mathrm{W} / \mathrm{m}^{2}$ \\
\hline $\mathrm{m}_{\text {tank }}$ & $\begin{array}{l}\text { mass of water stored in the } \\
\text { tank }\end{array}$ & $\mathrm{kg}$ \\
\hline$\dot{\mathrm{m}}$ & $\begin{array}{l}\text { mass flow rate though the } \\
\text { collector }\end{array}$ & $\mathrm{kg} / \mathrm{s}$ \\
\hline$\dot{\mathrm{Q}}_{\mathrm{u}}$ & $\begin{array}{l}\text { useful energy collected by the } \\
\text { solar collector }\end{array}$ & $\mathrm{W} / \mathrm{m}^{2}$ \\
\hline $\mathrm{T}_{\mathrm{a}}$ & ambient temperature & ${ }^{\circ} \mathrm{C}$ \\
\hline $\mathrm{T}_{\mathrm{b}}$ & $\begin{array}{l}\text { absorber average surface } \\
\text { temperature }\end{array}$ & ${ }^{\circ} \mathrm{C}$ \\
\hline $\mathrm{T}_{\mathrm{C}}$ & $\begin{array}{l}\text { transparent cover average } \\
\text { surface temperature }\end{array}$ & ${ }^{\circ} \mathrm{C}$ \\
\hline $\mathrm{T}_{\mathrm{c}, \mathrm{i}}$ & $\begin{array}{l}\text { water temperature at collector } \\
\text { inlet }\end{array}$ & ${ }^{\circ} \mathrm{C}$ \\
\hline $\mathrm{T}_{\mathrm{c}, \mathrm{o}}$ & $\begin{array}{l}\text { water temperature at collector } \\
\text { outlet }\end{array}$ & ${ }^{\circ} \mathrm{C}$ \\
\hline $\mathrm{T}_{\mathrm{f}}$ & $\begin{array}{l}\text { mean water temperature } \\
\text { within the spherical collector }\end{array}$ & ${ }^{\circ} \mathrm{C}$ \\
\hline $\mathrm{U}_{\mathrm{L}}$ & overall heat loss coefficient & $\mathrm{W} / \mathrm{m}^{2^{\circ}} \mathrm{C}$ \\
\hline
\end{tabular}

\section{Greek symbols}

$\begin{array}{cc}\alpha & \text { absorptance } \\ \eta & \text { collector hourly efficiency } \\ \eta_{D} & \text { collector daily efficiency } \\ \eta_{I} & \text { collector instantaneous } \\ \tau & \text { efficiency } \\ \tau & \text { transmittance }\end{array}$

$(\tau \alpha)_{\text {ave }}$ daily average transmittance-

$\begin{array}{cc}\text { Subscripts } & \text { absorptance } \\ \text { A } & \text { ambient } \\ \text { B } & \text { absorber } \\ \text { C } & \text { transparent cover } \\ \text { C } & \text { collector } \\ \text { D } & \text { daily } \\ \text { F } & \text { mean water } \\ \text { I } & \text { inlet } \\ \text { L } & \text { losses } \\ \text { O } & \text { outlet } \\ \text { sph } & \text { spherical } \\ \text { T } & \text { total } \\ \text { U } & \text { useful }\end{array}$

\section{INTRODUCTION}

olar-thermal energy conversion is one of the most efficient ways to use sun's radiation as renewable energy. Because of thermal conversion efficiency had been the main topic of the research field, modern technical solutions and new materials were used in solar-thermal industry. The solar thermal energy systems can be used in solar water-heating systems, solar pool heaters, and solar space-heating systems. Solar collector is one of the most active systems which are used in solar-thermal energy industry. This system absorbs the incoming solar radiation, converting it into heat at the absorbing surface, and transfers this heat to a fluid (usually air or water) flowing through the collector. The heated fluid carries the heat either directly for using or to be stored in order to be used when the solar radiation is absent. Solar water heaters can be classified according to its pattern such as Rectangular, triangle and trapezoidal shaped built-in-storage.

Also, it can be classified into two categories according to water storage structure of the heaters:

1) Solar water heaters which have collection and storage in separated units.

2) Solar water heaters which have collection and storage in one unit (built-in-storage).

Combining the collector and the storage tank into one unit has a lot of advantages as it is better in heat transfer since there is no pipe, no fins and no bonding resistance. It also has lower flow resistance and simplified construction.

In this study, performance of a fixed spherical solar collector with built-in-storage water heater is done experimentally. The major advantage of the spherical pattern is that, there is no need for a special orientation or any tracking mechanism for this collector to receive maximum solar energy. Due to its spherical shape, all orientations have the same effect. Furthermore, its spherical shape provides low resistance to wind.

\section{A. Literature review}

Flat-plate solar collectors are commonly used because of its simplicity in construction and can be operated easily. It consists of a glass or plastic cover (called the glazing) and a dark-colored absorber plate. These collectors heat liquid or air at temperatures up to $80^{\circ} \mathrm{C}$. To increase the annual thermal energy gain from the collector, it must be tilted and oriented at optimum angle. This tilt angle is depending on the location latitude. Generally, previous studies show that the optimum tilt angle which gives the maximum heat gain equals to the location latitude angle [2]. Tracking mechanism can be used to increase the incident solar radiation which means increasing the thermal conversion efficiency. The incident solar radiation on the tracking system is 1.45 times higher than that of a fixed collector [3]. However, tracking mechanism is more expensive in construction, operation and maintenance because of its moving parts and its needs of power supply. 
Energy gained from solar collectors depends not only on materials and technologies used in its construction but also on the geometry of the solar collector absorber [13].

Watts [4] invented solar collector apparatus equipped with self-contained illumination means. The apparatus comprises a generally spherical collector from upper and lower hemispherically shaped halves coupled together. A generally spirally wound heat exchanger disposed interiorly in the collector at the centre there of warms a fluid with solar energy. A mirror disposed below the heat exchanger reflects solar energy toward it to improve efficiency. Incandescent lights disposed below the mirror within the spherical collector may be actuated to provide an aesthetically and useful lighting effect at night.

Sokolov and Vaxman [5] performed a comparative study in which a rectangular shaped tank and a triangular shaped tank were tested. Although both systems showed similar efficiencies, temperature gradient in the rectangular system was larger than that in the triangular one.

Kaushik et al. [6] presented a mathematical model for a triangular built-in-storage type solar water heater with $11.5^{\circ}$, $30^{\circ}, 45^{\circ}$, and $60^{\circ}$ inclination angle. It was observed that the water temperature was higher at $45^{\circ}$.

A. Mohamad [7] studied a built-in solar collector with trapezoidal cross section design. To prevent reverse circulation at night-time, the collector contains a thermal diode. Thermal efficiency of the collector with trapezoidal cross section was about $50 \%$ as the thermal diode provides an increase of $10 \%$ in the storage tank efficiency.

Cruz et al.[8] investigated the performance of a trapezoidal-shaped solar collector/energy store with a constant tilt angle of $45^{\circ}$. The maximum temperature under these conditions was found to be $31^{\circ} \mathrm{C}$ for a power input of 600 $\mathrm{W} / \mathrm{m} 2$ with storage ability to $66 \mathrm{~L}$.

Joudi et al. [9] investigated numerically the performance of a prism shaped storage solar collector with a right triangle cross sectional area by using ANSYS software. Temperature distribution, velocity distribution inside the storage solar collector, stored energy and mean tank temperature were determined. The results show that the value of the temperature variation within the storage solar collector depends mainly on the solar radiation intensity. The maximum recorded value of the temperature difference was $12.8^{\circ} \mathrm{C}$ in winter and $11.3^{\circ} \mathrm{C}$ in summer during clear sky conditions.

Moravej [10] investigated experimentally the efficiency of a conical solar collector. The results show that the average efficiency of a conical solar collector with $1 \mathrm{~m} 2$ of absorber plate and $0.6 \mathrm{~m}$ diameter is about $53 \%$.

Spherical surfaces can be used in solar collectors which will keep the benefits of the tracking systems by considering that the incident beam radiation is always normal to the receiving hemisphere. This means that the collector will be able to track the sun without moving the collector mechanically.

Samanta and Al Balushi [11] estimated the annual average solar radiation incident on spherical shape solar collector with a separated storage and compared it with a tilted flat plate solar collector. The annual average of the daily incident solar radiation was increased by $21 \%$ when using spherical solar collector.

Bakir [12] made an experimental research which indicated that the conversion efficiency for built-in-spherical solar collector was $79 \%$ at low outlet temperature (below $32^{\circ} \mathrm{C}$ ).

Gasper et al. [13] estimated the annual average incident solar radiation on a spherical solar collector which indicated that the annual average incident solar radiation was about $6 \%$ higher than that of the flat plate collector. Semi-spherical solar collector was compared with evacuated tube solar collector by Pelece [14] who indicated that the thermal conversion efficiency of a semi-spherical solar collector is about 1.4 times smaller than of the evacuated tube solar collector.

Gasper et al. [15] studied experimentally the difference between the spherical shape and flat plate absorber exposed to the sun without transparent cover. The overall daily average temperature on the spherical absorber is 1.34 smaller than on flat plate. The difference between maximum and minimum temperatures of the spherical absorber surface was $30^{\circ} \mathrm{C}$. According to the literature survey; few researches investigated the geometry design of the absorber shape.

\section{B. Scope of the present work}

The main aim of the present work is investigating the efficiency of spherical solar collector for water heating and the effects of flow rate and incident solar radiation on the collector outlet temperature and the temperature distribution inside the sphere.

\section{EXPERIMENTAL WORK}

\section{A. Introduction}

The experimental set-up is constructed at faculty of Engineering, Mansoura University, Egypt. The different materials used in manufacturing are commercially available. The study was performed in December 2015, January and February 2016 at climatic conditions of Mansoura (31.23 ${ }^{\circ} \mathrm{E}$ and $\left.31.04^{\circ} \mathrm{N}\right)$.

\section{B. Description of Apparatus}

The apparatus used in this investigation is a spherical solar collector for water heating which has a spherical absorber (built-in-tank) and a spherical transparent polycarbonate cover. Water enters at the bottom and leaves at the top of the collector though well insulated pipes of $2.5 \mathrm{~cm}$ in diameter. Major components of the apparatus are shown in Figure (2.1). Heating of water occurs in the absorber which has a volume of $113 \mathrm{~L}$ as shown in Figures (2.2) and (2.3).

Spherical shape transparent cover with $70 \mathrm{~cm}$ in diameter, consisted of two pieces as top and a bottom hemisphere, is manufactured. It was made of rigid polycarbonate sheet with thickness of $1.25 \mathrm{~mm}$. On the inner side of this cover, 6 thermocouples were located and fixed by silicon. These thermocouples are distributed in the similar way as those on the absorber surface. Three of these thermocouples are located 
on the upper hemisphere and the remaining three thermocouples are located on the lower hemisphere.

The second part of the collector is a spherical absorber surface with two pieces as upper and lower hemispheres inside the spherical cover. It was made of galvanized iron sheet with thickness of $1.25 \mathrm{~mm}$ where the diameter of the absorber is 60 $\mathrm{cm}$. These two pieces were assembled by bolts and nuts and to prevent leakage of water a rubber gasket was placed with silicon between them. It was coated with Matt black board paint. On outer surface of the spherical absorber, sixteen thermocouples were located and fixed by a metallic epoxy adhesive.

Metallic frame made of copper is placed inside the absorber to carry nineteen thermocouples wiring which measured the mean temperature of water inside the absorber. These thermocouples were arranged to measure water temperature at distances of 5 and 15 and $30 \mathrm{~cm}$ from the absorber inner surface to the center of the built-in tank as shown in Figure (2.4).

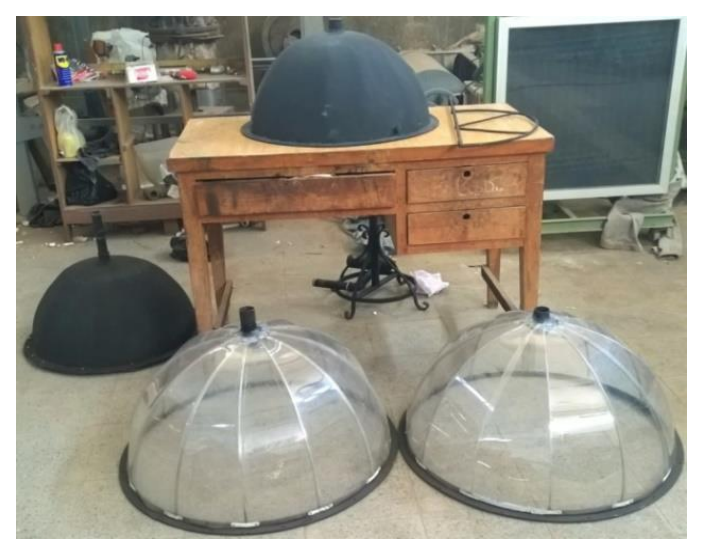

Fig. (2.1) Absorber and transparent cover of the collector

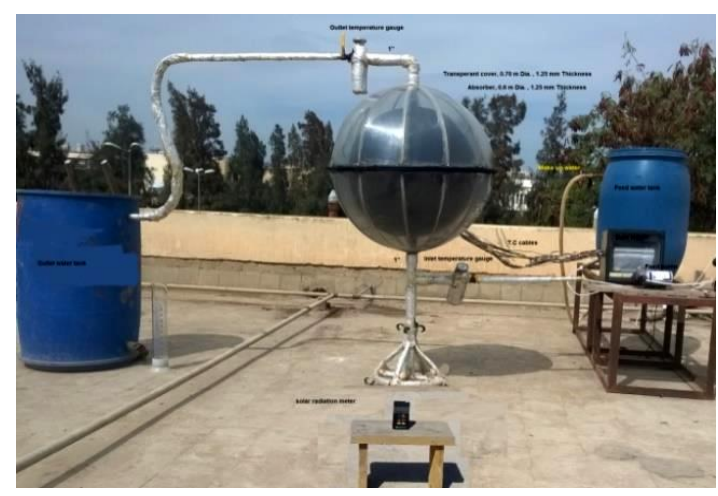

Fig. (2.2) General view of the experimental setup

\section{C.Measuring devices}

1) Solar radiation intensity:

Solar radiation intensity had been measured by using TES. 1333R Data logging solar power meter with an accuracy of $\pm 10 \mathrm{~W} / \mathrm{m} 2$ and range of $0-2000 \mathrm{~W} / \mathrm{m} 2$. Data are recorded on the horizontal surface for 30 second step.

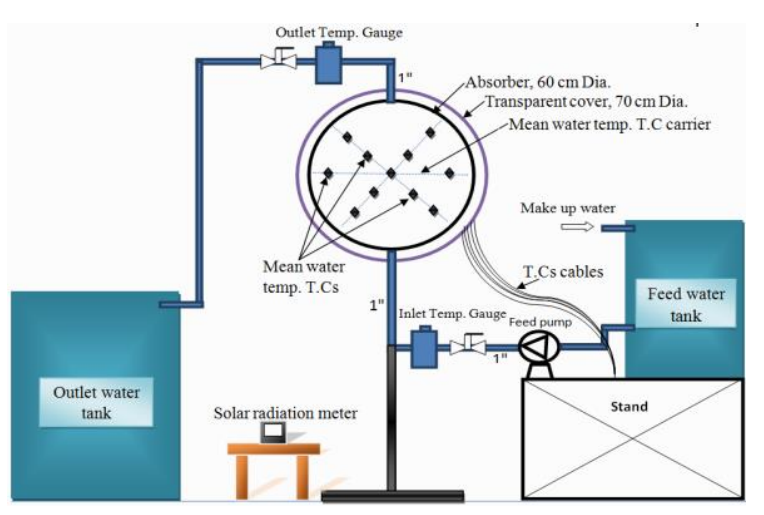

Fig. (2.3) Schematic diagram of the experimental apparatus

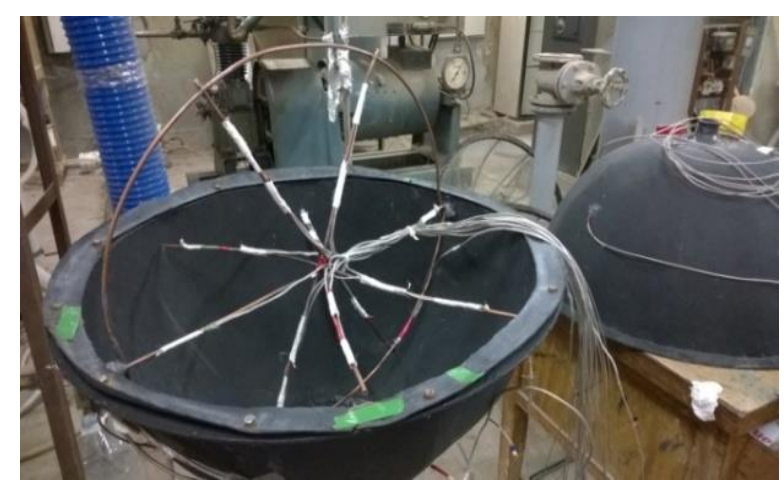

Fig. (2.4) Thermocouples distribution inside the sphere

2) Temperature measurements:

Temperatures are recorded each half an hour. Thermocouples of type K, $0.5 \mathrm{~mm}$ diameter had been used. The measuring instrument has a resolution 0.01 and the accuracy of the thermocouples $\pm 0.5{ }^{\circ} \mathrm{C}$. All of thermocouples were connected to yokogawa $\mu \mathrm{R} 180$ chart recorder. Inlet and outlet water temperatures were measured by using temperature thermometer while ambient temperature was measured by using glass thermometer. The following temperatures were measured for the spherical solar collector components:

(a) Transparent cover average surface temperature (Tc).

(b) Absorber average surface temperature (Tb).

(c) Mean water temperature within the spherical collector (Tf).

(d)Inlet water temperature (Tc,i).

(e) Outlet water temperature $(\mathrm{Tc}, \mathrm{o})$.

\section{3) Flow rate measurements:}

Water mass flow rate was indicated by measuring the amount of water collected in a calibrated flask of 1 liter capacity with an accuracy of $\pm 1 \mathrm{ml}$ during a measured period of time.

\section{D). Collector hourly and daily efficiency}

Collector efficiency is defined as the ratio of the useful energy collected, $(\mathrm{Q})^{\mathrm{e}} \mathrm{u} \mathrm{u}$, to the solar energy reaching to the 
surface. So, the instantaneous efficiency can be written as follows [2]:

$\eta_{I}=\frac{\dot{Q}_{u}}{\mathrm{G}_{T s p h} \mathrm{~A}_{T}}$

Where $\dot{Q}_{u}$ the useful energy which can be evaluated from the next equation:

$\dot{Q}_{u}=\dot{\mathrm{m}}_{\mathrm{w}} \mathrm{c}_{\mathrm{p}, \mathrm{w}}\left(\mathrm{T}_{\mathrm{c}, \mathrm{o}}-\mathrm{T}_{\mathrm{c}, \mathrm{i}}\right)+\left.\mathrm{m}_{\operatorname{tank}} \mathrm{c}_{p, w} \frac{\mathrm{dT}_{\mathrm{f}}}{\mathrm{d} \tau}\right|_{t}$

Hourly efficiency may be calculated by the integration of the above equation which gives:

$\eta=\frac{\left(\dot{\mathrm{m}}_{\mathrm{w}} \mathrm{c}_{\mathrm{p}, \mathrm{w}}\left(\int_{\mathrm{t}_{\text {Initial }}}^{\mathrm{t} \text { final }}\left(\mathrm{T}_{\mathrm{c}, \mathrm{o}}-\mathrm{T}_{\mathrm{c}, \mathrm{l}}\right) \mathrm{dt}\right)\right.}{\int_{\mathrm{t}_{\text {initial }}}^{\mathrm{t}} \mathrm{G}_{T s p h} \mathrm{~A}_{T} \mathrm{dt}}+$
$\frac{\left(\mathrm{m}_{\text {tank }} \mathrm{c}_{p, w}\left(\mathrm{~T}_{\mathrm{f}, \text { final }}-\mathrm{T}_{\mathrm{f}, \text { initial }}\right)\right)}{\int_{\mathrm{t}_{\text {initial }}}^{\mathrm{t}} \text { final }} \mathrm{G}_{T s p h} \mathrm{~A}_{T} \mathrm{dt}$

The average daily efficiency of the spherical solar collector can be evaluated from the following expression

$\eta_{D}$

$=\frac{\sum\left[\left(\dot{\mathrm{m}}_{\mathrm{w}} \mathrm{c}_{\mathrm{p}, \mathrm{w}}\left(\mathrm{T}_{\mathrm{c}, \mathrm{o}}-\mathrm{T}_{\mathrm{c}, \mathrm{i}}\right) d t+\mathrm{m}_{\text {tank }} \mathrm{c}_{p, w}\left(\mathrm{~T}_{\mathrm{f}, \text { final }}-\mathrm{T}_{\mathrm{f}, \text { initial }}\right)\right]\right.}{\sum \mathrm{G}_{T s p h} \mathrm{~A}_{T} d t}$

\section{E). Collector efficiency factor}

Collector efficiency factor $\bar{F}$, is an important performance parameter which may be useful to evaluate the design of the spherical solar collector. The collector efficiency factor can be defined as the ratio of the actual useful energy gain to the useful energy gain if the whole collector surface were at the mean fluid temperature in the collector [2]. Thus,

$\overline{\mathrm{F}}=\frac{\dot{Q}_{u}}{\dot{\mathrm{S}}_{T}-\mathrm{A}_{T} \mathrm{U}_{\mathrm{L}}\left(\mathrm{T}_{\mathrm{f}}-\mathrm{T}_{\mathrm{a}}\right)}$

Where $\mathrm{Tf}$ is the mean water temperature within the spherical collector. By applying the least squares fit to the obtained experimental data of $\eta$ and (Tf-Ta) /GTsph, according to equation (12), the collector efficiency factor $\bar{F}$, can be obtained [2].

$\eta=\bar{F}(\tau \alpha)_{a v e}-\bar{F} U_{L}\left(\frac{T_{f}-T_{a}}{G_{T s p h}}\right)$

F). Cost analysis comparison between spherical solar collector and tilted flat plate solar collector

Cost estimation for various components used in the present solar collector is given in Table (2.1). The objective is to keep the cost as low as possible. Many factors affect the cost of warmed water obtained from a solar collector unit. Both capital and running costs are influenced by materials of manufacturing, unit size, and site location.

The main economic advantages of solar collectors are, it is not required much infrastructure, simple to locally design and easy to install, operate and maintain.
TABLE (2.1)

FABRICATION COST OF THE SYSTEM

\begin{tabular}{l||l||l}
\multicolumn{1}{c||}{ Item } & $\begin{array}{l}\text { Tilted flat plat } \\
\text { solar collector }\end{array}$ & $\begin{array}{c}\text { Spherical } \\
\text { solar } \\
\text { collector }\end{array}$ \\
\cline { 2 - 3 } \multicolumn{1}{c||}{ Cost \$ } & Cost \$ \\
\hline Absorber & 12 & 22.5 \\
\hline Transparent cover & 15 & 29 \\
\hline $\begin{array}{l}\text { Tank }(113 \mathrm{~L}) \\
\left(0.5 \times 0.5 \times 0.45 \mathrm{~m}^{3}\right)\end{array}$ & 22.5 & \\
\hline Insulation & 4 & 2 \\
\hline Piping (inlet \& outlet $)$ & 6 & 5 \\
\hline Inner Pipe & 27 & 5 \\
\hline Valves & 10 & 2 \\
\hline Paint & 4 & 3 \\
\hline Carrier steel structure & 18 & 57 \\
\hline Machine Shop Labor & 30 & $125.5 \$$ \\
\hline Total cost \$ & $148.5 \$$ &
\end{tabular}

The better economic return on the investment depends on the production cost of the warmed water and its applicability. Economic analysis of solar collector water heater unit is given. The CRF (capital recovery factor), the FAC (fixed annual cost), the SFF (sinking fund factor), the ASV (annual salvage value), average annual productivity (M) and $\mathrm{AC}$ (annual cost) are the main calculation parameters used in the cost analysis of the solar collector unit. The AMC (annual maintenance operation cost) of the solar collector is required for cleaning of the transparent cover. As the system life passes on, the maintenance on it also increases. Therefore, $10 \%$ of the net present cost has been considered as maintenance cost. Finally, the CPL (cost of kW.hr) can be calculated by dividing the annual cost of the system $\mathrm{AC}$ by annual production of the solar collector (M). The above mentioned calculation parameters can be expressed as [16]:

$C F R=\frac{i(1+i)^{n}}{(1+i)^{n-1}}$

$F A C=P(C R F)$

$S F F=\frac{i}{(1+i)^{n-1}}$

$S=0.2 P$

$A S V=S(S F F)$

$A M C=0.15 F A C$

$A C=F A C+A M C-A S V$

$C P L=\frac{A C}{M}$

Where $\mathrm{P}$ is the present capital cost of solar collector, $\mathrm{i}$ is the interest per year, which is assumed as $12 \%, \mathrm{n}$ is the number of life years, which is assumed as 10 years in this analysis. Table(5) shows the cost of liter from spherical solar collector such as present capital $\operatorname{cost}(\mathrm{P})$, the $\mathrm{CRF}$, the FAC, the SFF, the ASV, the AMC, the AC, average annual productivity (M) and CPL. 
TABLE (2.2)

SHOWS THE COST OF LITER FROM SPHERICAL AND FLAT PLATE SOLAR COLLECTOR

\begin{tabular}{c||c||c||l||c} 
Item & $\begin{array}{c}\mathbf{P} \\
\mathbf{( \$ )}\end{array}$ & $\mathbf{S}$ & $\begin{array}{c}\mathbf{M} \\
\mathbf{( k W . h r})\end{array}$ & $\begin{array}{c}\mathbf{C P L} \\
\mathbf{( \$ )}\end{array}$ \\
\hline $\begin{array}{c}\text { Flat plate solar } \\
\text { collector }\end{array}$ & 149 & 29.7 & 1808 & 0.0119 \\
\hline $\begin{array}{c}\text { Spherical solar } \\
\text { collector }\end{array}$ & 126 & 25.1 & 2812 & 0.0065
\end{tabular}

From the economic analysis it can be found that the cost of $1 \mathrm{~kW} . \mathrm{hr}$ of energy gain from the spherical solar collector is about $44 \%$ lower than that of the flat plate solar collector.

\section{RESULTS AND DISCUSSIONS}

\section{A. Introduction}

There are many factors affecting the performance and efficiency of the solar collector as climate variables, design parameters and operating conditions. From previous review, the major parameters affecting the efficiency and performance of the solar collector are; solar radiation intensity and ambient temperature. These factors will be tested and discussed below according to the experimental data.

\section{B. Measuring of solar radiation intensity and ambient temperature}

Figures (3.1), (3.2) show the collected data of the total solar radiation which is carried out in different days, based on typical readings of all day's chosen from December 2015, January and February 2016

Measurements show that the mean hourly solar radiation takes its maximum value on 24/2/2016 and records a peak at 11:00 am to be $(949 \mathrm{~W} / \mathrm{m} 2)$ with average hourly solar radiation of that day of $(635 \mathrm{~W} / \mathrm{m} 2)$. The solar radiation on 22/12/2015 records the lowest mean solar radiation especially during the period of rainfall from 11:40 am to $12: 45 \mathrm{pm}$ with average hourly solar radiation of $(323 \mathrm{~W} / \mathrm{m} 2)$.

Figures (3.3), (3.4) depict the ambient temperature along the sun light hours during the measurement days. From this curves, it can be noticed that, the highest ambient temperature is related to the highest incident solar radiation 24/2/2016 experiment which records its peak of $25^{\circ} \mathrm{C}$ at 3:00 pm with average daily ambient temperature about $22.3^{\circ} \mathrm{C}$ while the lowest ambient temperature curve is recorded during $16 / 1 / 2016$ experiment day which has a maximum peak of $19.5^{\circ} \mathrm{C}$ at $3: 00 \mathrm{pm}$ with average daily ambient temperature about $19^{\circ} \mathrm{C}$.

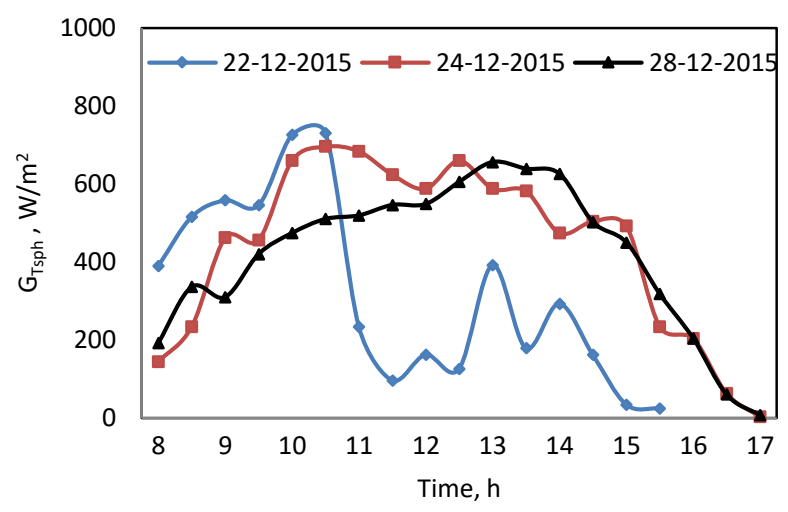

Fig. (3.1) Mean hourly incident solar radiation incident during non-flow rates operation tests

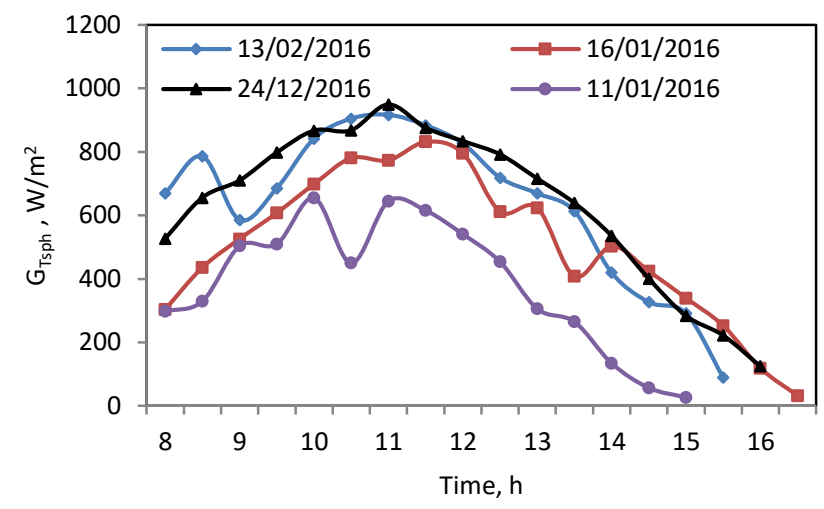

Fig. (3.2) Mean hourly incident solar radiation incident during operation tests done with flow rates

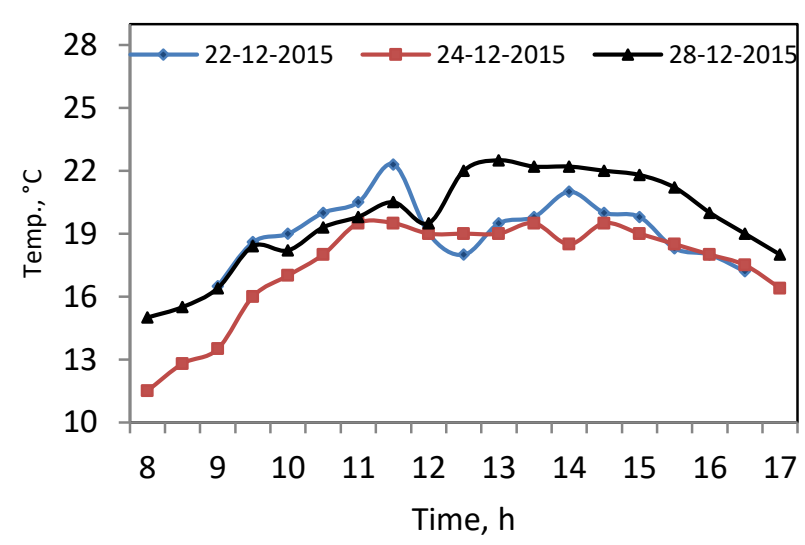

Fig. (3.3) Ambient temperature variation during operation tests done with flow rates 


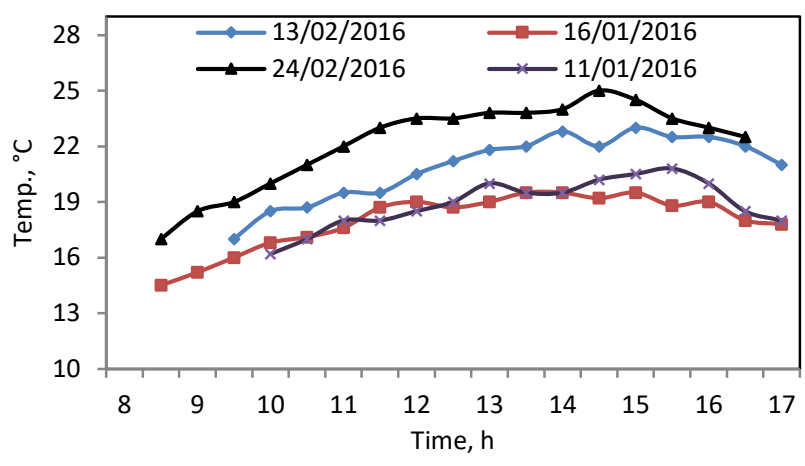

Fig. (3.4) Ambient temperature variation during non-flow rates operation tests

C.Temperature behavior of the measured points in the collector

All temperatures measured during the operation tests are taken every half hour starting about 8:30 am to 5:00 pm. Average temperature is evaluated for each of transparent cover, absorber temperature and water temperature inside the sphere. Recorded values of different temperature measured and the total incident solar radiation on the collector during the experimental tests are presented in Figures (3.5), (3.6), (3.7) for non-flow rate experiments. For all non-flow rate experiments, the spherical collector is filled with fresh water before the experiment and measurements are started after 30 minutes. The fresh water temperature in the non-flow experiment was $15^{\circ} \mathrm{C}, 15.8^{\circ} \mathrm{C}$ and $14^{\circ} \mathrm{C}$ on $22 / 12 / 205$, $24 / 12 / 2015$ and $28 / 12 / 2015$ experiments respectively.

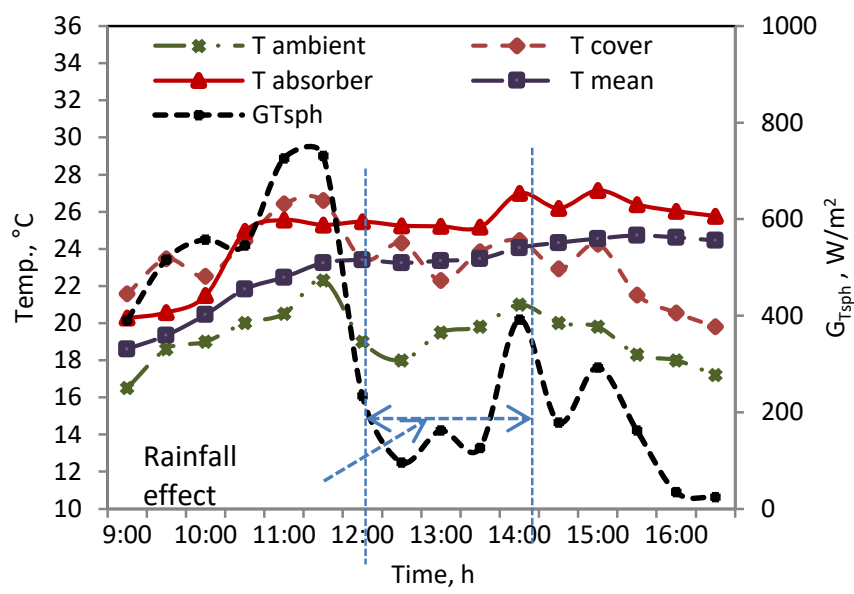

Fig. (3.5) Average collector's cover, absorber, Tf, Ta and GTsph on 22-122015

It is clear that the transparent cover temperature reflects a good response to the variation of the incidence solar radiation, where the transparent cover temperature changes for all curves. On the other hand, the absorber surface temperature depends on the weather condition as its temperature variation for the rainfall test day $(22 / 12 / 2015)$ and the cloudy test day $(24 / 12 / 2015)$ differ from the partly sunny test day
$(28 / 12 / 2015)$.

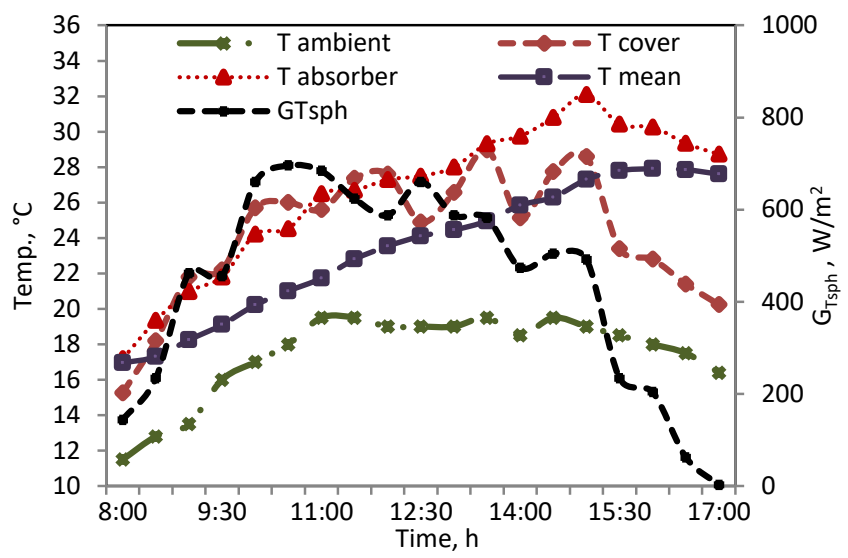

Fig. (3.6) Average collector's cover, absorber, Tf, Ta and GTsph on 24-122015

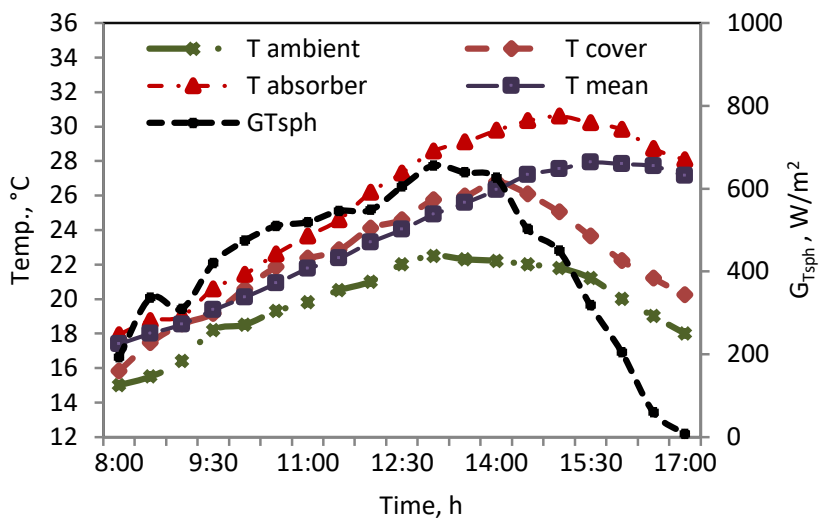

Fig. (3.7) Average collector's cover, absorber, Tf, Ta and GTsph on 28-122015

It is noticed also the peak zone of the average absorber temperature is shifted from the peak zone of the incident solar radiation. The temperature distribution for the (28/12/2015) experiment is more stable and smoothly build-up its temperature which reflects that the effect of clouds and rainfall on the absorber thermal behavior. For the storage water mean temperature inside the collector, it is clear that its variation is more stable and doesn't been affected by the instantaneous variation of the incidence solar radiation. This behavior is due to the high thermal capacity of water and the large amount of stored water and the greenhouse effect of the transparent cover.

Average temperatures variation during operation tests which were done with flow rate though the collector on transparent cover, absorber, mean water temperature, inlet and outlet water with total incident solar radiation were registered and presented in Figures (3.8), (3.9), (3.10) and (3.11).

From these curves, it can be noticed that $\left(30.5^{\circ} \mathrm{C}, 25^{\circ} \mathrm{C}\right)$ are the maximum and the minimum peak of the outlet water temperature which occur at $20 \mathrm{~L} / \mathrm{h}$ and $50 \mathrm{~L} / \mathrm{h}$ respectively while $\left(24.5^{\circ} \mathrm{C}, 20^{\circ} \mathrm{C}\right)$ are the maximum and the minimum peaks of the mean water temperature which occur also at 20 $\mathrm{L} / \mathrm{h}$ and $50 \mathrm{~L} / \mathrm{h}$ respectively. 


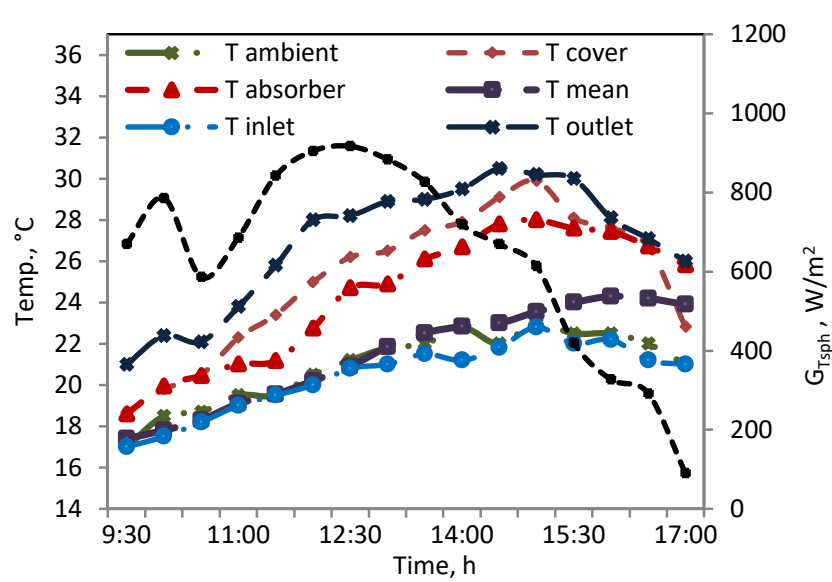

Fig. (3.8) Average collector's cover, absorber, Tf, Ta, GTsph, Tc,in, Tc,o with flow rate $20 \mathrm{~L} / \mathrm{h}$ on $13-02-2016$

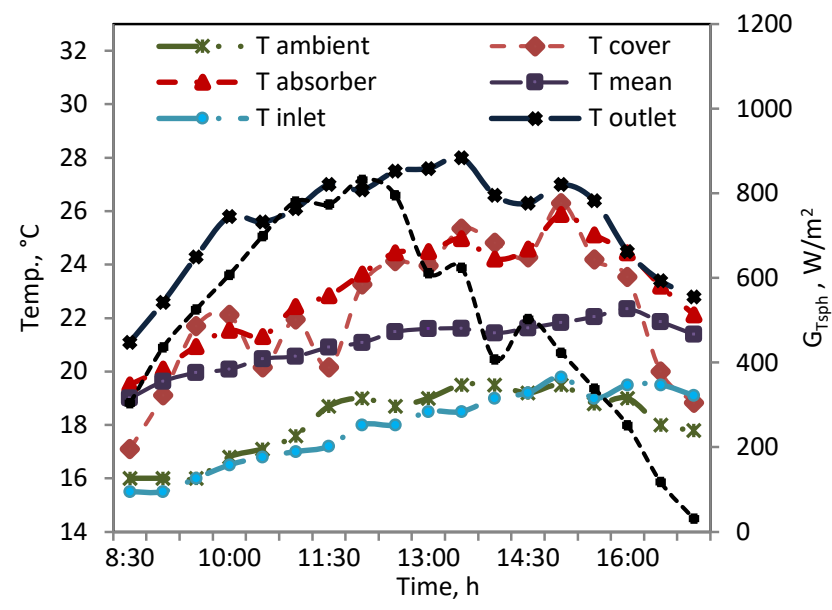

Fig. (3.9) Average collector's cover, absorber, Tf, Ta, GTsph, Tc,in, Tc,o with flow rate $30 \mathrm{~L} / \mathrm{h}$ on $16-01-2016$

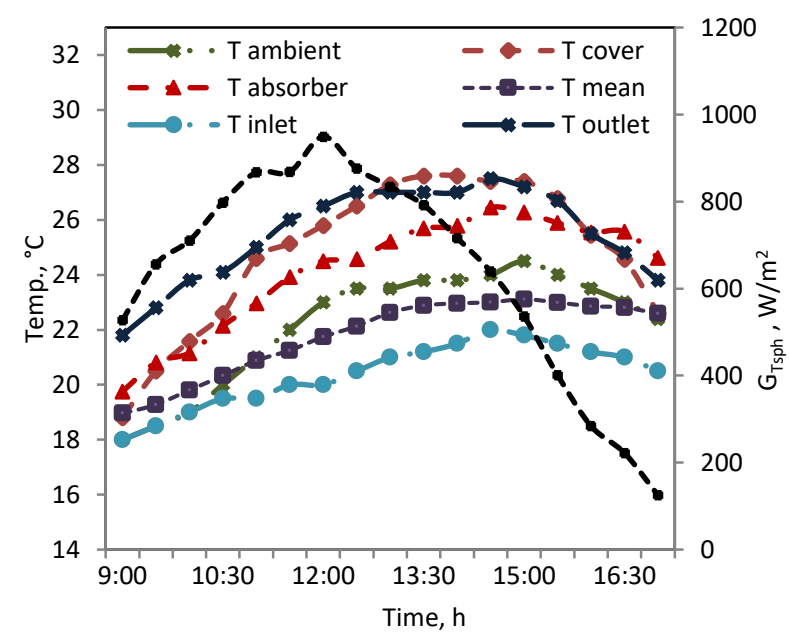

Fig. (3.10) Average collector's cover, absorber, Tf, Ta, GTsph, Tc,in, Tc,o with flow rate $40 \mathrm{~L} / \mathrm{h}$ on $24-02-2016$

Also it can be observed that the outlet water temperature is higher than that of mean water temperature where the large surface area of the absorber rise the boundary layer film of the storage water, this film rises up by bouncy to be collected at the top rather than mixed with the whole water in the sphere. So, the top zone of the sphere is considered to be the hottest zone of the storage sphere.

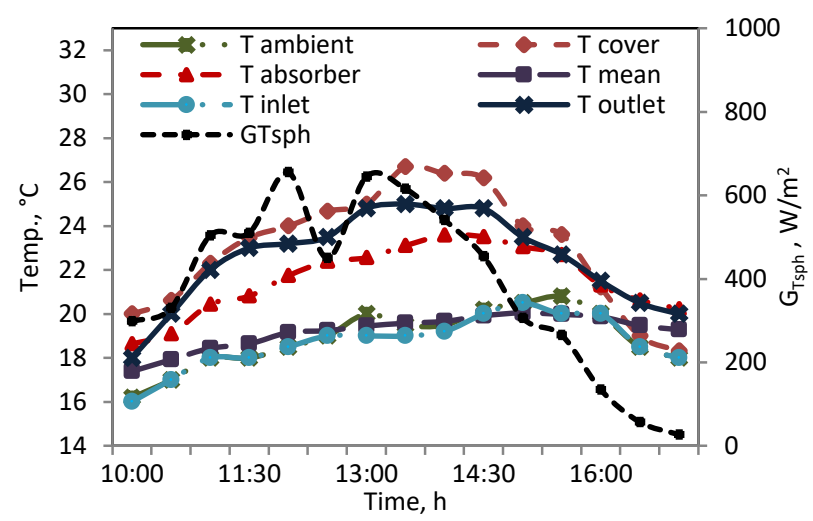

Fig. (3.11) Average collector's cover, absorber, Tf, Ta, GTsph, Tc,in, Tc,o with flow rate $50 \mathrm{~L} / \mathrm{h}$ on 11-01-2016

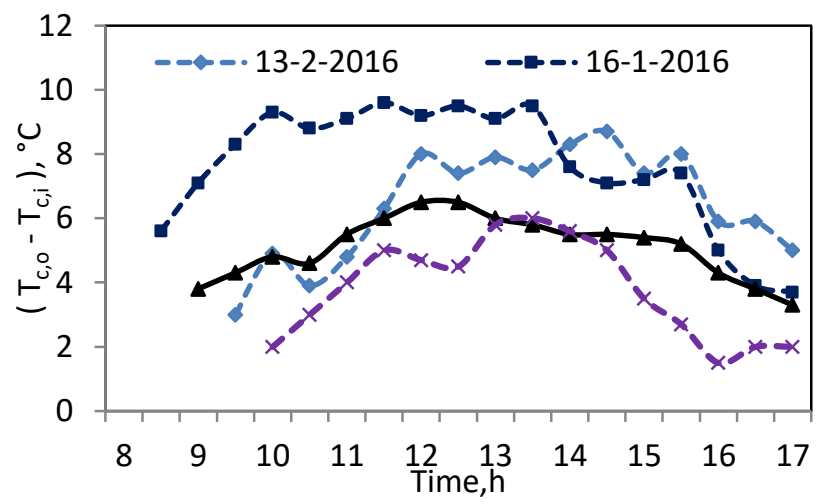

Fig. (3.12) Difference between the outlet and the inlet water temperature

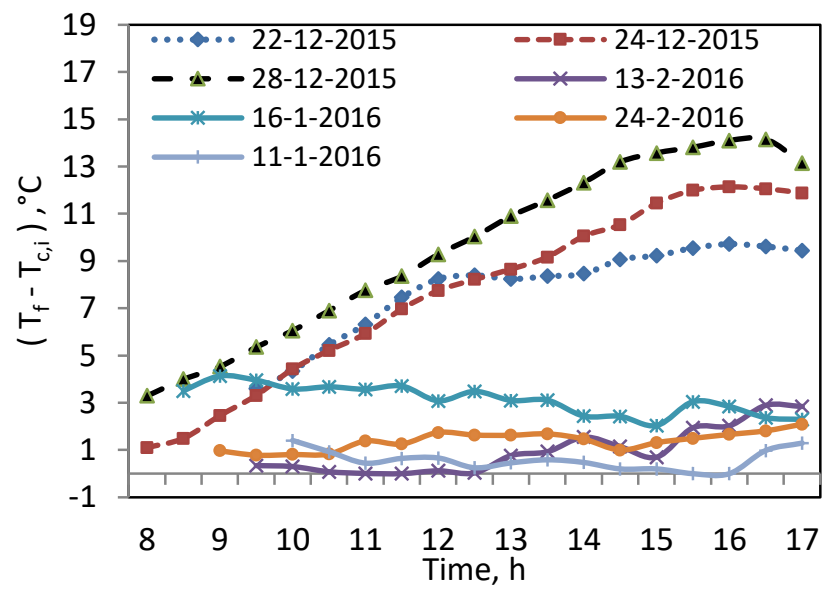

Fig. (3.13) Difference between mean water temperature and inlet water temperature

Figure (3.12) shows the hourly temperature rise between the collector outlet and inlet water temperature at different flow rates. The $(50 \mathrm{~L} / \mathrm{h})$ experiment gives the minimum 
temperature rise with average value of $3.8^{\circ} \mathrm{C}$ where $(30 \mathrm{~L} / \mathrm{h})$ experiment gives the maximum average temperature rise to be $7.6^{\circ} \mathrm{C}$.

Figure (3.13) illustrates the temperature difference between the water mean temperature ( $\mathrm{Tf}$ ) and the inlet water temperature for operation days with water flow rate and between the water mean temperature (Tf) and the initial water temperature which is the filling water at the non-flow experiments start-up.

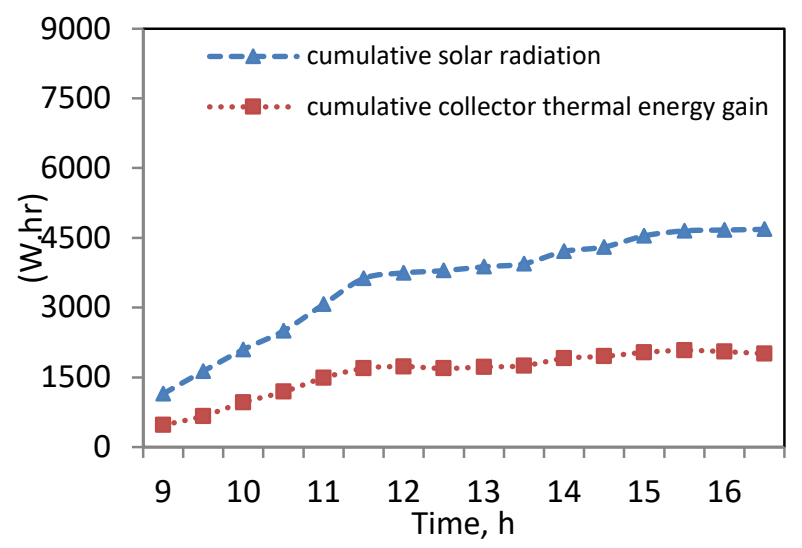

Fig. (3.14) Hourly variation cumulative experimental for incident solar radiation and the collector thermal energy gain for 22/12/2015, Non-flow rate condition

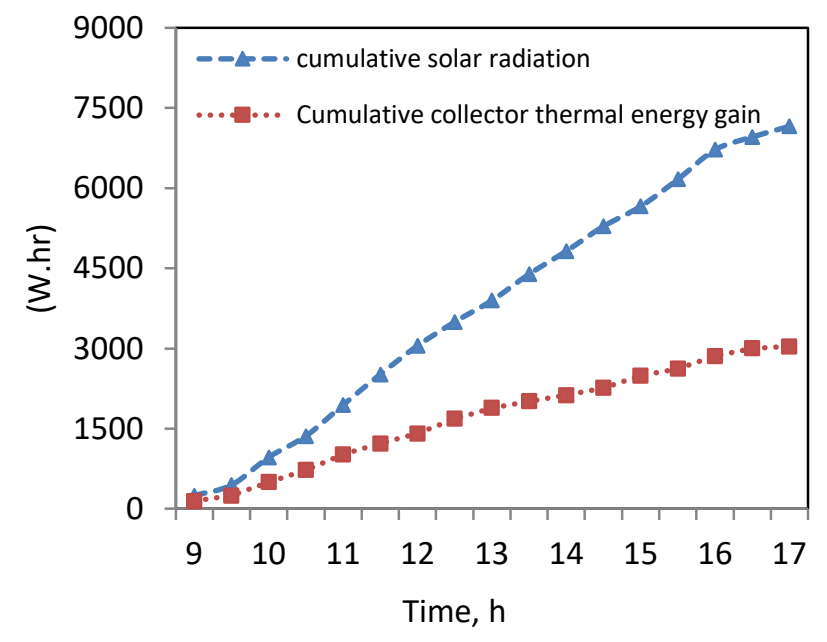

Fig. (3.15) Hourly variation cumulative experimental for incident solar radiation and the collector thermal energy gain for 24/12/2015, Non-flow rate condition

It can be noticed that for non-flow experiments, which were carried out on 22/12/2015, 24/12/2015 and 28/12/2015, the temperature difference increases gradually to reach its maximum value at approximately $4: 00 \mathrm{pm}$ to be $14.5^{\circ} \mathrm{C}$ on 28/12/2015 operation day while the temperature difference for the experiments with flow rate it reaches $3^{\circ} \mathrm{C}$ which concludes that most of heat gained are collected at the top of the sphere and a small amount of heat gained is stored in the sphere.
D.The cumulative solar radiation incident versus the cumulative collector thermal energy gain

The daily cumulative solar radiation incident and the cumulative collector thermal energy gain during sunlight hours for the spherical solar collector is shown in Figures (3.14) to (3.20).

The cumulative solar radiation incident on $1.1304 \mathrm{~m} 2$ total surface area of absorber, as well as the cumulative daily amount of thermal energy gain during sunlight hours for the spherical solar collector, are shown in Figures (3.14), (3.15) and (3.16) for the different days with non-flow rate condition. Comparing the results of the three days $(22,24$ and $28 / 12 / 2015)$, it can be noticed the rate of increase of accumulated energy is higher for 28/12/2015 and lower for $22 / 12 / 2015$ and this can be explained due to rainfall in 22/12/2015 from 12:15 pm to about 13:15 pm. This may demonstrate the effect of weather fluctuation on the efficiency and energy gain of the solar collector.

Figures from (3.18) to (3.21) show the cumulative incident solar radiation and the cumulative collector thermal energy gain for (13/2/2016), (16/1/2016), (24/2/2016) and $(11 / 2 / 2016)$ experiments with a maximum peak of cumulative collector thermal energy gain to be $5700 \mathrm{~W} . \mathrm{hr}$ for $(24 / 2 / 2016)$ experiment with $30 \mathrm{~L} / \mathrm{h}$ flow rate while the minimum peak of cumulative collector thermal energy gain was $4450 \mathrm{~W} . \mathrm{hr}$ for (13/2/2016) experiment with $20 \mathrm{~L} / \mathrm{h}$ flow rate.

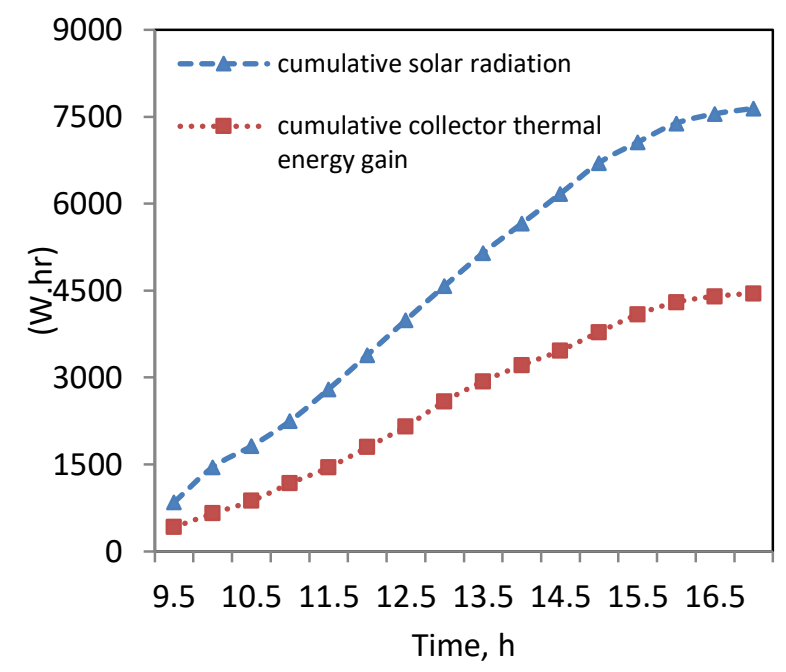

Fig. (3.16) Hourly variation cumulative experimental for incident solar radiation and the collector thermal energy gain for 28/12/2015, Non-flow rate condition 


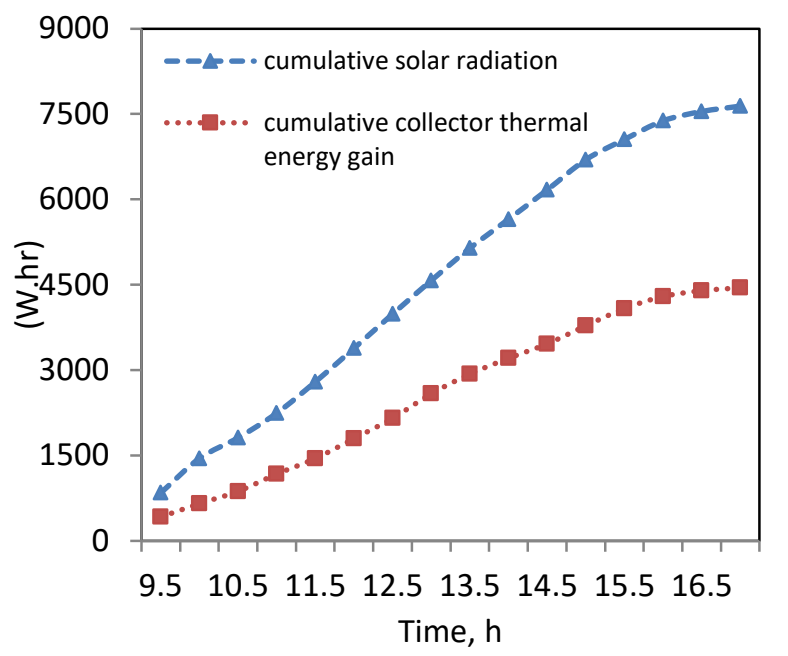

Fig. (3.17) Hourly variation cumulative experimental for incident solar radiation and the collector thermal energy gain with flow rate $20 \mathrm{~L} / \mathrm{h}$ on $13 / 02 / 2016$

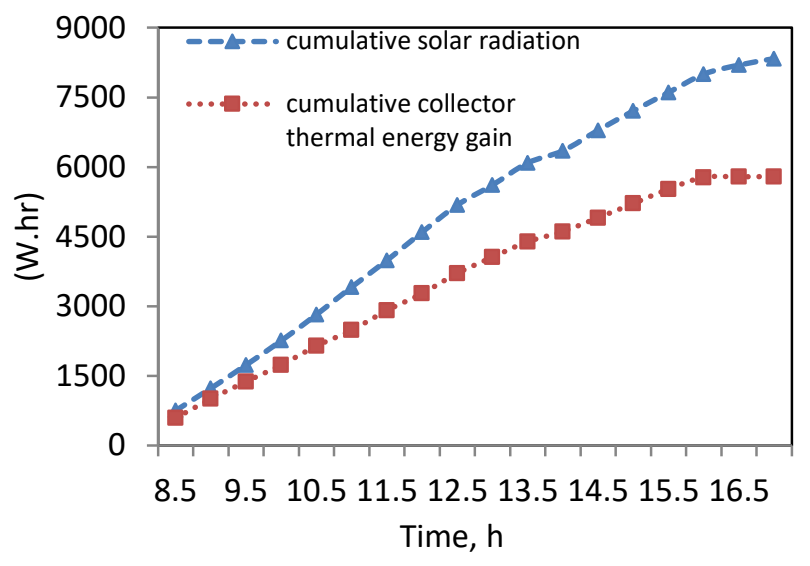

Fig. (3.18) Hourly variation cumulative experimental for incident solar radiation and the collector thermal energy gain with flow rate $30 \mathrm{~L} / \mathrm{h}$ on $16 / 01 / 2016$

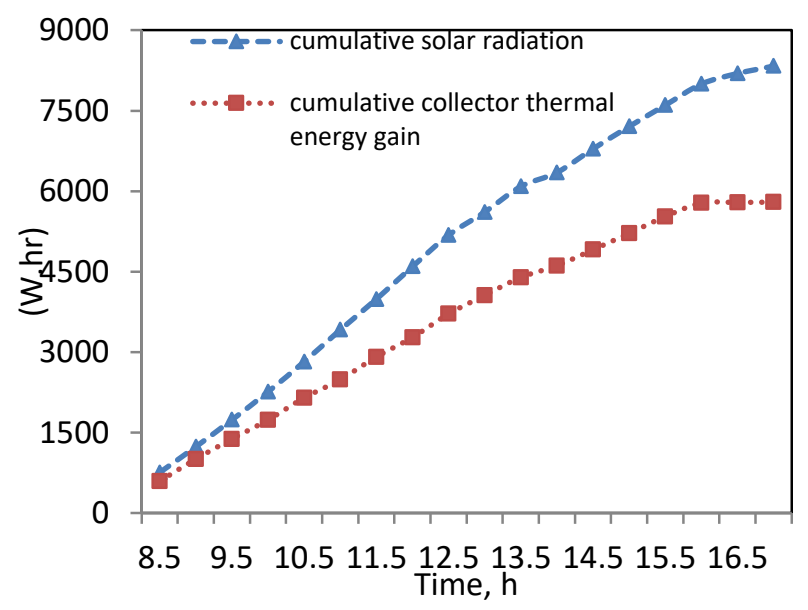

Fig. (3.19) Hourly variation cumulative experimental for incident solar radiation and the collector thermal energy gain with flow rate $40 \mathrm{~L} / \mathrm{h}$ on $24 / 02 / 2016$

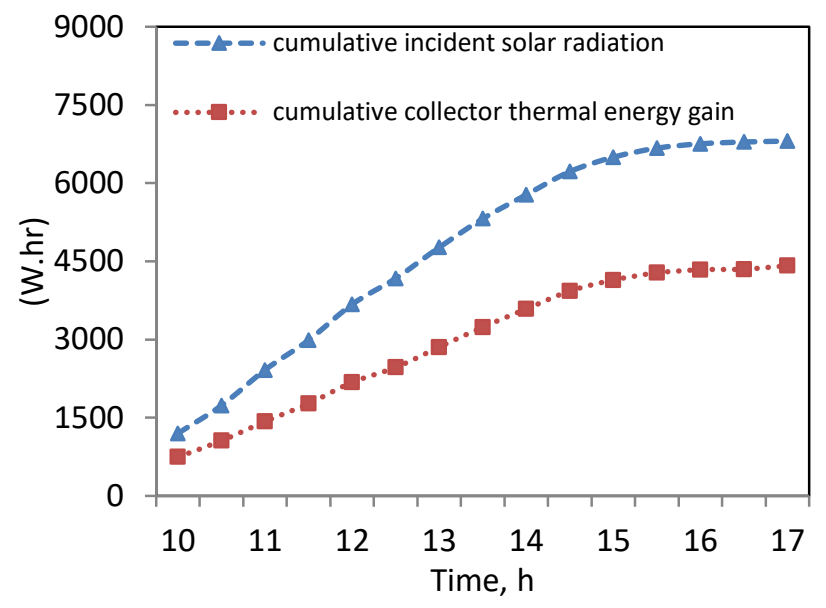

Fig. (3.20) Hourly variation cumulative experimental for incident solar radiation and the collector thermal energy gain with flow rate $50 \mathrm{~L} / \mathrm{h}$ on $11 / 01 / 2016$

\section{E. Collector efficiency factor}

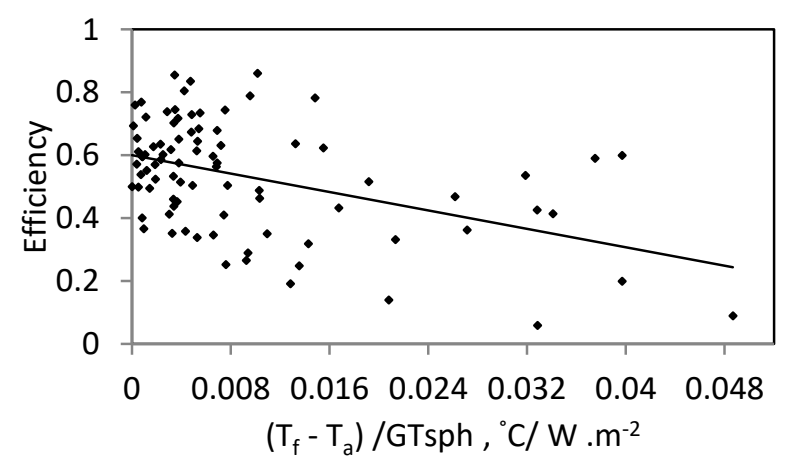

Fig, (3.21) Performance curve for the spherical solar collector

The performance curve of the spherical solar collector which demonstrate the relation between the hourly collector efficiency and the temperature difference of the stored water and the ambient temperature with respect to the total incident solar radiation indicated that the collector factor efficiency and the overall heat loss coefficient will be 0.924 and $7.8 \mathrm{~W} / \mathrm{m} 2{ }^{\circ} \mathrm{C}$ respectively with assuming that the $(\tau \alpha)$ ave is constant for all experiment tests days with a value of 0.65 .

\section{F. Average daily efficiency}

Table (3.1) shows the average daily efficiency with inlet water temperature, ambient temperature and water mass flow rate for each operation test

It is clear that the daily average efficiency increases with increasing water mass flow rate through the collector but due to heat gain from the surrounding to the collector, the daily average efficiency of $(30 \mathrm{~L} / \mathrm{h}$ and $40 \mathrm{~L} / \mathrm{h})$ experiments is more than the daily average efficiency of $(50 \mathrm{~L} / \mathrm{h})$ experiment as ambient temperature is greater than inlet water temperature.

While the average daily efficiency of conical [10], rectangular [5] and trapezoidal [8] solar collector reaches 0.53 , 
0.57 and 0.48 , the spherical solar collector average daily efficiency reaches 0.69 as it will be a self-tracking solar collector.

\begin{tabular}{c||c||c||l||l}
\multicolumn{1}{c||}{ Date } & $\begin{array}{c}\text { Flow } \\
\text { rate } \\
(\mathbf{L} / \mathbf{h})\end{array}$ & $\begin{array}{c}\text { Ambient } \\
\text { temperature } \\
\left({ }^{\circ} \mathbf{C}\right)\end{array}$ & $\begin{array}{c}\text { Inlet water } \\
\text { temperature } \\
\left({ }^{\circ} \mathbf{C}\right)\end{array}$ & $\begin{array}{c}\text { Average } \\
\text { daily } \\
\text { efficiency } \\
(\mathbf{\%})\end{array}$ \\
\hline $22 / 12 / 2015$ & 0 & 19.2 & 15 & 42.8 \\
\hline $24 / 12 / 2015$ & 0 & 17.45 & 15.8 & 42.4 \\
\hline $28 / 12 / 2015$ & 0 & 19.65 & 14 & 40.5 \\
\hline $13 / 2 / 2016$ & 20 & 20.9 & 20.4 & 58 \\
\hline $16 / 1 / 2016$ & 30 & 19.2 & 17.5 & 68.6 \\
\hline $24 / 2 / 2016$ & 40 & 22.2 & 20.4 & 69 \\
\hline $11 / 1 / 2016$ & 50 & 18.9 & 18.7 & 64.8
\end{tabular}

\section{Conclusion}

In this investigation, the efficiency of the spherical solar collector with an absorber with diameter $60 \mathrm{~cm}$ and ransparent cover with diameter of $70 \mathrm{~cm}$ are experimentally performed. The experiments are conducted at three non-flow rate cases and different flow rates $(20,30,40$ and $50 \mathrm{~L} / \mathrm{h})$. From the experiments results, the following conclusions can be considered:

A. The daily collector efficiency, which is defined as the ratio of the daily useful heat gain to the daily total solar insolation on the spherical solar collector, increases with decreasing the fluid inlet temperature or increasing mass flow rate of the fluid.

B. The performance curve of the spherical solar collector indicated that the collector factor efficiency and the overall heat loss coefficient will be 0.924 and $7.8 \mathrm{~W} / \mathrm{m} 2{ }^{\circ} \mathrm{C}$ respectively with assuming that the $(\tau \alpha)$ ave is constant for all experiment tests days with a value of 0.65 .

C. According to the experiments climate condition and the collector design, the maximum daily average collector outlet water temperature rise occurs with $(30 \mathrm{~L} / \mathrm{h})$ flow rate with value of $7.6{ }^{\circ} \mathrm{CA}$ conclusion section is not required. Although a conclusion may review the main points of the paper, do not replicate the abstract as the conclusion. A conclusion might elaborate on the importance of the work or suggest applications and extensions.

\section{REFERENCES}

[1] The annual report of Egypt New \& Renewable Energy Authority (NREA), 2013-2014, available online: http://www.moee.gov.eg/test_new/report.aspx.

[2] J. Duffie, W. Beckman, Solar Engineering of Thermal Processes. 4th edition, John Wiley \& Sons Inc. (1991).

[3] M. Lave, J. Kleissl, Optimum fixed orientations and benefits of tracking for capturing solar radiation in the continental United States. Renewable Energy, Vol. 36, pp. 1145-1152 (2011).

[4] Illuminated solar energy collector, available online: http://www.google.ch/patents/US4355628.

[5] M. Sokolov, B. Vaxman, Analysis of an Integral Compact Solar Water Heater. Solar Energy, Vol. 30, pp. 237-246 (1983).

[6] S. Kaushik, R. Kumar, H. Garg, J. Prakash, Transient Analysis of a Triangular Built-in-Storage Solar Water Heater under Winter Conditions. Heat Recovery Systems and CHP, Vol. 14, No. 4, pp. 337-341 (1994).

[7] A. Mohamad, Integrated solar collector storage tank system with thermal diode, Solar Energy, Vol. 61, No. 3, pp. 211-218 (1997).

[8] J. Cruz, G. Hammond, A. Reis, Thermal performance of a trapezoidalshape solar collector/ energy store, Applied Energy, Vol. 73, pp. 195-212 (2002)

[9] K. Joudi, I. Hussein, A. Farhan, Computational Model for a Prism Shaped Storage Solar Collector with a Right Triangular Cross Section. Energy Conversion and Management, Vol. 45, pp. 391-409 (2004).

[10] M. Moravej, Experimental Investigation of Efficiency of a Novel Conical Solar Collector. Science Journal (SCJ), Vol. 36, No. 4, pp. 691-699 (2015).

[11]B. Samanta, K. Al Balushi, Estimation of Incident Radiation on a Novel Spherical Solar Collector. Renewable Energy, Vol. 14, No. 1-4, pp. 241247 (1998).

[12]O. Bakir, Experimental Investigation of a Spherical Solar Collector. Middle East Tech. Univ., Ankara, Master Diss., pp. $72-85$ (2006).

[13]F. Gaspar, M. Balan, L. Jantschi, V. Ros, Evaluation of Global Solar Radiation Received by a Spherical Solar Collector. Bulletin UASVM Agriculture, Vol. 69, No. 6, pp.128-135 (2012).

[14] I. Pelece, Semi-spherical solar collector for water heating. Proceedings of the International Scientific Conference "Engineering for rural development", Latvia University of Agriculture, pp. 211-215 (2010).

[15]F. Gaspar, T. Deac, L. Tutunaru, D. Moldovanu, Experimental Study on the Sun Tracking Ability of a Spherical Solar Collector. Energy Procedia, Vol. 85, pp. 220 - 227 (2016).

[16] A. Kabeel, A. Hamed, Cost analysis of different solar still configurations, Energy 35, pp. 2901-2908 (2010). 